DOI: 10.17707/AgricultForest.65.1.14

\author{
Fatmir FAIKU, \\ Liridon BUQAJ, Arben HAZIRI ${ }^{1}$
}

\title{
PHYTOCHEMICALS AND ANTIOXIDANT STUDY OF TEUCRIUM CHAMAEDRYS (L.) PLANT
}

\begin{abstract}
SUMMARY
Phytochemicals and antioxidant activity were analysed to the extracts of aerial part of Teucrium chamaedrys (L.) plant growing wild in Peja (Western part of Kosovo) in two different altitude levels (790 m and $520 \mathrm{~m}$ ). In extracts were analysed the total phenols and flavonoids by spectrophotometric methods. Total phenols were determined by Folin-Ciocalteu reagent and were in the range of $21.45 \mathrm{mg} / \mathrm{g}$ (in altitude of $790 \mathrm{~m}$ ) to $237.51 \mathrm{mg} / \mathrm{g}$ in altitude of $520 \mathrm{~m}$ (expressed as gallic acid equivalent, mg GAE/g).The amounts of flavonoids in the extracts of Teucrium chamaedys (L.) were in the range of $11.85 \mathrm{mg} / \mathrm{g}$ (in altitude of 520 $\mathrm{m})$ to $84.50 \mathrm{mg} / \mathrm{g}$ in altitude of $790 \mathrm{~m}$ (expressed as rutin equivalent, mg RU/g). Antioxidative activity was determined in vitro by using the DPPH test. Experimental values are expressed as $\mathrm{IC}_{50}$ values $(\mu \mathrm{g} / \mathrm{mL})$, and they shows that the tested extracts have high antioxidant activities, which range in scope from $18.40 \mu \mathrm{g} / \mathrm{mL}$ (in altitude $790 \mathrm{~m}$ ) to $264.22 \mu \mathrm{g} / \mathrm{mL}$ (in altitude $520 \mathrm{~m}$ ).

Keywords: Teucrium chamaedrys (L.), phenols, flavonoids, antioxidant activity.
\end{abstract}

\section{INTRODUCTION}

The genus Teucrium L. (Lamiaceae) includes about 200 species and subspecies of herbs and shrubs, often aromatic, with a centre of distribution in the Mediterranean basin (Greuter et al., 1986). In the area of central and west Balkan, nine species of this genus was registered (Tutin et al., 1972). The herbs of Teucrium chamaedrys (L.) and Teucrium montanum (L.) are the most popular traditional remedies in Balkans used as cholagogue, tonic and antianemic, as well for treatment of diarrhea, leucorrhea, wounds and hemorrhoids. The infusion of aerial parts of Teucrium scordium was used as bitter aromatic, cholagogue with wound healing and fever reducing properties (Redžić, 2007; Jarić et al., 2007).

Antimicrobial and antioxidant activity, total phenolic and flavonoid concentrations of Teucrium species have been studied by a number of researchers in the different parts of the world (Kucuk et al., 2006; Sarker et al., 2007 Gursoy

\footnotetext{
${ }^{1}$ Fatmir Faiku, Arben Haziri (corresponding author: arbeni77chem@hotmail.com), Faculty of Natural Sciences, Department of Chemistry, University of Prishtina, Prishtinë,10000, KOSOVO; Liridon BUQAJ, Faculty of Life and Environmental Sciences, University of Prizren, Ukshin Hoti, Prizren, 20000, KOSOVO.

Notes: The authors declare that they have no conflicts of interest. Authorship Form signed online.
} 
et al., 2009; Nevcihan et al., 2009; Stanković et al., 2010; Kundaković et al., 2011; Stanković et al., 2012; Vlase et al., 2014).

Our research group was interested to analyse the chemical profile of different medicinal plants, which are growing wild in the region of Kosovo and Albania (Faiku et al., 2012, 2013, 2015a,b, 2016, 2017a,b, 2018; Haziri et al., 2009, 2010, 2013, 2017a,b).

The aim of this research was to determine the quantity of phenols, flavonoids and antioxidant activity of the different extracts from Teucrium chamaedrys (L.) growing wild in Peja (Western part of Kosovo).

\section{Plant material}

\section{MATERIAL AND METHODS}

The aerial part of Teucrium chamaedrys (L.), growing wild in east part of Kosovo, was collected in May 2017. The plants were dried at room temperature.

\section{Preparation of plant organic extracts}

A portion of the finely powdered material $(200 \mathrm{~g})$ was extracted three times with 70\% methanol (methanol, $4 \mathrm{~L}$ ) during a 24-h period. After removal of methanol under reduced pressure, the aqueous phase was successively extracted with three solvents of increasing polarity, namely ethanol, ethyl acetate and acetone. The extraction was carried out until a colorless extract was obtained. The residue was the aqueous extract. All five extracts (ethyl acetate, methanol, water, ethanol and acetone) were evaporated to dryness and then dissolved in $50 \%$ ethanol to make $10 \%(\mathrm{w} / \mathrm{v})$ solutions. These solutions, either as such or in diluted state, were used in subsequent experiments.

\section{Determination of total phenolic and flavonoid content}

The amount of total phenolic contents in the extracts was determined spectrophotometrically with the Folin Ciocalteu (FC) reagent using the method of Fukumoto and Mazza (Fukumoto et al., 2000), with small modifications (Bozin et al., 2008). The reaction mixture contained $1.0 \%$ dilution of examined extracts $(100 \mu \mathrm{L})$, freshly prepared $0.2 \mathrm{~mol} / \mathrm{L} \mathrm{FC}$ reagent $(2.5 \mathrm{~mL})$ and $10 \%$ sodium carbonate solution $(2 \mathrm{~mL})$. The mixture was incubated in the dark at room temperature for 1 hour to complete the reaction. The absorbance of the resulting solution was measured at $760 \mathrm{~nm}$ on a UV/VIS spectrophotometer using distilled water as the blank. The concentration of total phenolic contents was expressed in mg gallic acid equivalents (GAE) per g dried extract (d.e.), using a standard curve of gallic acid $(0.1-2.0 \mu \mathrm{g} / \mathrm{mL})$. All measurements were replicated five times.

Total flavonoid content in the extracts was determined spectrophotometrically according to Zhishen et al. 1999, using a method based on the formation of a flavonoid-aluminium complex with an absorbance maximum at $430 \mathrm{~nm}$. The examined extracts $(1 \mathrm{~mL})$ were mixed with $2 \% \mathrm{AlCl}_{3} \times$ $6 \mathrm{H}_{2} \mathrm{O}(0.5 \mathrm{~mL})$. After incubation at room temperature for $30 \mathrm{~min}$, the absorbance of the reaction mixtures was measured. The blank sample was a 1:1 mixture of the examined extracts and distilled water. Flavonoid content was expressed in $\mu \mathrm{g}$ 
rutin equivalent (RE) per g dried extract by using a standard curve of rutin (concentration range $0.5-6.0 \mu \mathrm{g} / \mathrm{mL}$ ). All measurements were replicated five times.

\section{Antioxidant activity- DPPH assay}

The DPPH assay was performed as described previously (Blois, 1958; Zhou et al., 2004), following the transformation of the DPPH radical to its reduced, neutral form (DPPH-H). The samples of all extracts of Teucrium chamaedrys (L.) (from 2.50 to $50.00 \mu \mathrm{g} / \mathrm{mL}$ ) were mixed with $90 \mu \mathrm{M} \mathrm{DPPH} \cdot$ solution $(1 \mathrm{~mL})$ and made up with $95 \%$ methanol to a final volume of $4 \mathrm{~mL}$. The absorbance of the resulting solutions was recorded spectrophotometrically at 515 $\mathrm{nm}$ after $1 \mathrm{~h}$ at room temperature, against the blank (with the same chemicals, except for the sample). The same procedure was repeated with rutin and tertbutyl-4- hydroxyanisole (BHA) as a positive control. For each sample five replicates were recorded.

\section{RESULTS AND DISCUSSION}

The concentration of phenolics in the examined plant extracts using the Folin-Ciocalteu's reagent is expressed in terms of gallic acid equivalent. Results of the amount of total phenolic contents in Teucrium chamaedrys (L.) extracts are given in Table 1.

Table1. Total phenol contents in the plant extract expressed in terms of gallic acid equivalent (mg GAE)

\begin{tabular}{|l|l|l|l|l|l|}
\hline $\begin{array}{l}\text { Altitude } \\
(\mathrm{m})\end{array}$ & Ethanol & Methanol & $\begin{array}{l}\text { Ethyl } \\
\text { acetate }\end{array}$ & Acetone & Water \\
\hline 520 & $237.51 \pm 085^{1}$ & $164.12 \pm 0.18$ & $24.85 \pm 0.21$ & $138.20 \pm 0.15$ & $163.15 \pm 0.19$ \\
\hline 790 & $233.40 \pm 0.95$ & $161.50 \pm 0.25$ & $21.45 \pm 0.15$ & $125.40 \pm 0.20$ & $160.52 \pm 0.24$ \\
\hline
\end{tabular}

${ }^{1}$ Each value in the table vas obtained by calculating the average of five analysis \pm standard deviation

The amount of total phenolics in Teucrium chamaedrys (L.) extracts ranged from $21.45 \mathrm{mg} \mathrm{GAE} / \mathrm{g}$ (ethyl acetate extract to $790 \mathrm{~m}$ altitude) to 237.51 mg GAE/g (ethanol extract to $520 \mathrm{~m}$ altitude). The highest concentration of phenol was measured in ethanol, methanol and aqueous extract. Somewhat smaller concentration was found in acetone extract, while ethyl acetate extract had considerably smaller concentration of phenolics.

The content of phenolics in the plant extracts of the species Teucrium chamaedrys (L.) depends on the type of extract, i.e. the polarity of solvent used in extraction. The extracts obtained using more polar solvents like ethanol; methanol and water have higher concentration of phenolics (Table 1). High dissolubility of phenolics in polar solvents provides high concentration of these compounds in the extracts obtained using polar solvents for the extraction (Zhou et al., 2004).

The concentration of flavonoids in various plant extracts of the species Teucrium chamaedrys (L.) was determined using spectrophotometric method 
with aluminum chloride. The content of flavonoids was expressed in terms of rutin equivalent (mg RU/g). The amounts of flavonoids in the tested extracts are shown in Table 2.

Table 2. Flavonoid contents in the plant extract expressed in terms of rutin equivalent (mg RU/g)

\begin{tabular}{|l|l|l|l|l|l|}
\hline $\begin{array}{l}\text { Altitude } \\
(\mathrm{m})\end{array}$ & Ethanol & Methanol & Ethyl acetate & Acetone & Water \\
\hline 520 & $45.55 \pm 0.20^{1}$ & $56.0 \pm 0.62$ & $82.27 \pm 0.75$ & $69.52 \pm 0.55$ & $11.85 \pm 0.65$ \\
\hline 790 & $41.45 \pm 0.30$ & $58.50 \pm 0.55$ & $84.50 \pm 0.74$ & $72.10 \pm 0.62$ & $12.15 \pm 0.45$ \\
\hline
\end{tabular}

${ }^{1}$ Each value in the table vas obtained by calculating the average of five analysis \pm standard deviation

The concentration of flavonoids in plant extracts from Teucrium chamaedrys (L.) ranged from from $11.85 \mathrm{mg}$ RU/g (water extract to $520 \mathrm{~m}$ altitude) to $84.50 \mathrm{mg} \mathrm{RU} / \mathrm{g}$ (ethyl acetate extract to $790 \mathrm{~m}$ altitude). The concentration of flavonoids in acetone extract was $72.10 \mathrm{mg} \mathrm{RU} / \mathrm{g}$, which was very similar to the value of ethyl acetate extract concentration. The lowest flavonoid concentration was found in ethanol and aqueous extract. The concentration of flavonoids in plant extracts depends on the polarity of solvents used in the extract preparation (Min et al., 2005). Based on the obtained values for the concentration of flavonoids in the examined extracts of Teucrium chamaedrys (L.), it was found that the highest concentration of these compounds was in the extracts obtained using solvents of moderate polarity. The amount of total phenolic and total flavonoids in Teucrium chamaedrys (L.) extracts were given in Figure 1.

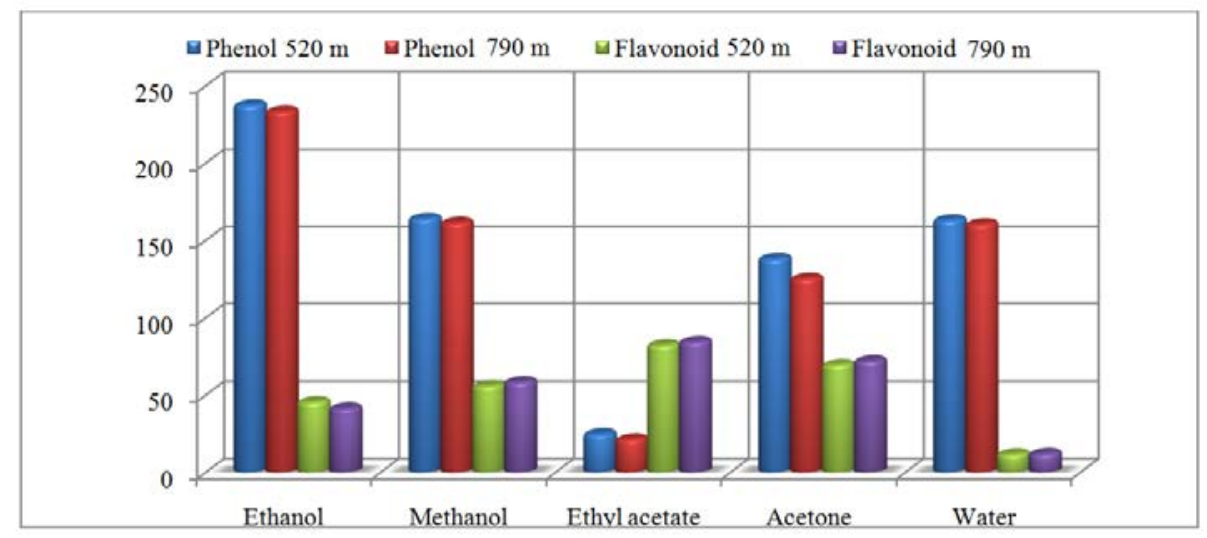

Figure 1. The amount of total phenolic contents and content of total flavonoids in Teucrium chamaedrys (L.) extracts

The antioxidant activity of Teucrium chamaedrys (L.) extracts has been evaluated in a series of in vitro tests. The DPPH radical is one of the most commonly used substrates for fast evaluation of antioxidant activity because of 
its stability (in radical form) and the simplicity of the assay. In the DPPH assay, the ability of the investigated extracts to act as donors of hydrogen atoms or electrons in transformation of DPPH into its reduced form DPPH-H was investigated (Table 3). Parallel to examination of the antioxidant activity of plant extracts, the values for three standard compounds were obtained and compared to the values of the antioxidant activity. The standard substances were 3-tert-Butyl4-hydroxyanisole (BHA) and rutin. Summary display of level for antioxidant activity of tested extracts is shown in Table 3.

Table 3. IC $_{50}$ values $(\mu \mathrm{g} / \mathrm{mL})$ of the neutralization of DPPH radical with Teucrium chamaedrys (L.) extracts

\begin{tabular}{|l|l|l|l|l|l|l|l|}
\hline $\begin{array}{l}\text { Altitude } \\
(\mathrm{m})\end{array}$ & Ethanol & Methanol & Ethyl acetate & Acetone & Water & BHA & Rutin \\
\hline 520 & $21.55 \pm 0.84^{1}$ & $24.55 \pm 0.85$ & $264.22 \pm 0.98$ & $29.95 \pm 1.1$ & $26.25 \pm 0.65$ & $5.25 \pm 0.78$ & $9.27 \pm 0.77$ \\
\hline 790 & $18.40 \pm 0.70$ & $25.60 \pm 0.70$ & $259.55 \pm 0.80$ & $27.41 \pm 0.90$ & $22.41 \pm 0.70$ & $5.25 \pm 0.78$ & $9.27 \pm 0.7$ \\
\hline
\end{tabular}

${ }^{1}$ Each value in the table vas obtained by calculating the average of five analysis \pm standard deviation

All of the assessed extracts of Teucrium chamaedrys (L.) were able to reduce the stable, purple-colored radical DPPH to the yellow-colored DPPH-H form with $\mathrm{IC}_{50}$ ( $50 \%$ of reduction) values as follows: $21.55 \mu \mathrm{g} / \mathrm{mL}$ in altitude 520 $\mathrm{m}$ and $18.40 \mu \mathrm{g} / \mathrm{mL}$ in altitude $790 \mathrm{~m}$ for ethanol, $24.55 \mu \mathrm{g} / \mathrm{mL}$ in altitude $520 \mathrm{~m}$ and $25.60 \mu \mathrm{g} / \mathrm{mL}$ in altitude $790 \mathrm{~m}$ for methanol, $264.22 \mu \mathrm{g} / \mathrm{mL}$ in altitude $520 \mathrm{~m}$ and $259.55 \mu \mathrm{g} / \mathrm{mL}$ in altitude $790 \mathrm{~m}$ for ethyl acetate, $29.95 \mu \mathrm{g} / \mathrm{mL}$ in altitude $520 \mu$ and $27.41 \mu \mathrm{g} / \mathrm{mL}$ in altitude $790 \mathrm{~m}$ for acetone, and $26.25 \mu \mathrm{g} / \mathrm{mL}$ in altitude $520 \mathrm{~m}$ and $22.41 \mu \mathrm{g} / \mathrm{mL}$ in altitude $790 \mathrm{~m}$ for water extract.

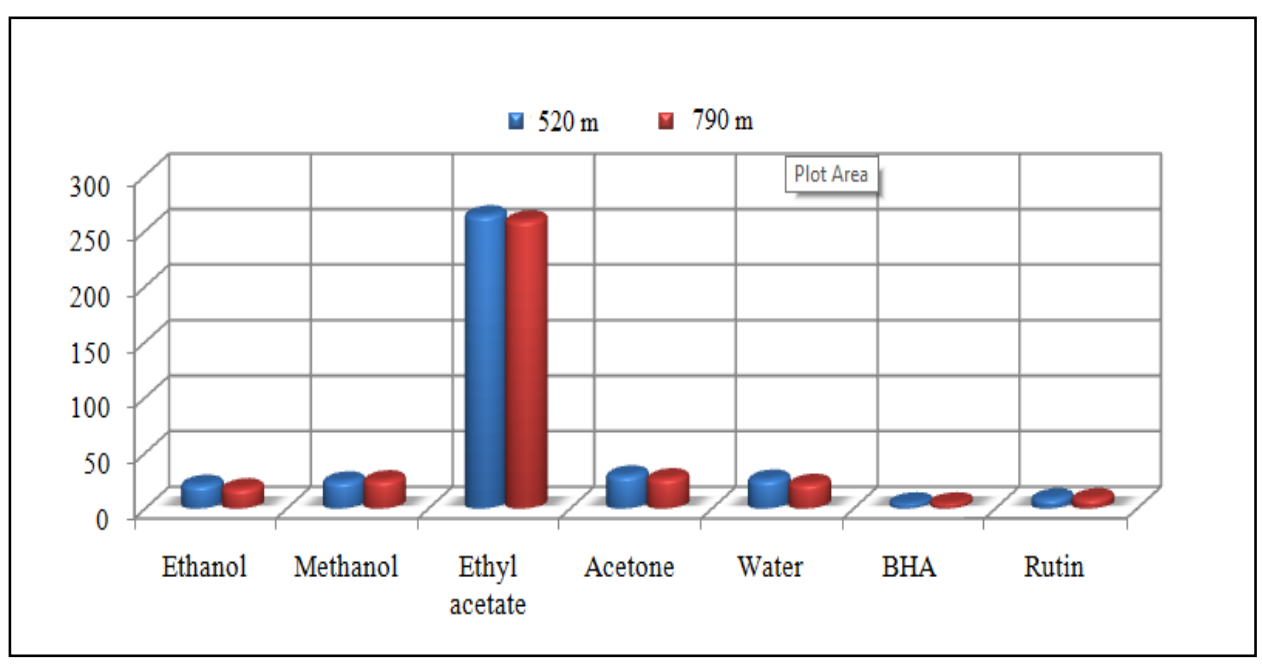

Figure 2. The $\mathrm{IC}_{50}$ values $(\mu \mathrm{g} / \mathrm{mL})$ of the neutralization of DPPH radical with Teucrium chamaedrys (L.) extracts 
The obtained values for antioxidant activity examined with DPPH radical are in the range of 264.22 to $18.40 \mu \mathrm{g} / \mathrm{ml}$. The largest capacity to neutralize DPPH radicals was found for ethanol extract, which neutralized $50 \%$ of free radicals at the concentration of $18.40 \mu \mathrm{g} / \mathrm{ml}$. A similar activity was found for water, methanol and acetone extracts whose IC $_{50}$ values were 22.41, 24.55 and $27.41 \mu \mathrm{g} / \mathrm{ml}$ respectively. The minutest capacity to inhibit DPPH radicals was determined for ethyl acetate extract. In comparison to $\mathrm{IC}_{50}$ values of BHA and rutin, ethanol, methanol, water and acetone extracts from Teucrium chamaedrys (L.) manifested the strongest capacity for neutralization of DPPH radicals. The IC $_{50}$ values $(\mu \mathrm{g} / \mathrm{mL})$ of the neutralization of DPPH radical with Teucrium chamaedrys (L.) extracts were given in Figure 2.

The extracts that perform the highest antioxidant activity (Table 3) have the highest concentration of phenolics (Table 1). Phenols are very important plant constituents because of their scavenging ability on free radicals due to their hydroxyl groups. Therefore, the phenolic content of plants may contribute directly to their antioxidant action (Tosun et al., 2009).

Flavonoids are class of secondary metabolites with significant antioxidant and chelating properties. Antioxidant activity of flavonoids depends on the structure and substitution pattern of hydroxyl groups (Sharififar et al., 2009). Ethyl acetate extract has a very high concentration of flavonoids as well, but it manifests less intense antioxidant activity, while aqueous extract has smaller content but manifests the antioxidant activity similar to methanol and acetone extracts. This difference is a result of different dissolubility of flavonoids in the solvents of different polarities.

\section{CONCLUSIONS}

The aim of this research was to determine the concentration of phenols, flavonoids and in vitro antioxidant activity of the different extracts from Teucrium chamaedrys (L.) growing wild in Peja (Western part of Kosovo). To conduct this type of research, we took two samples of the plant Teucrium chamaedrys (L.) at different altitudes $520 \mathrm{~m}$ and $790 \mathrm{~m}$. The amount of total phenols in organic extracts of Teucrium chamaedrys (L.) was in the region of $21.45 \mathrm{mg} \mathrm{GAE} / \mathrm{g}$ (ethyl acetate extract to $790 \mathrm{~m}$ altitude) to $237.51 \mathrm{mg}$ GAE/g (ethanol extract to $520 \mathrm{~m}$ altitude). Also, great amount of these compounds was found in the water extract (160.15 mg GAE/ g $790 \mathrm{~m}$ to $163.52 \mathrm{mg}$ GAE/ g de $520 \mathrm{~m}$ ). The amount of total flavonoids in organic extracts of Teucrium chamaedrys (L.) was in the region of $41.45 \mathrm{mg} \mathrm{RU} / \mathrm{g}$ (ethanol extract to $790 \mathrm{~m}$ altitude) to $84.50 \mathrm{mg} \mathrm{RU} / \mathrm{g}$ (ethyl acetate extract to $790 \mathrm{~m}$ altitude). Also, the amount of these compounds was found in the water extract (11.85 mg RU/ g 590 $\mathrm{m}$ to $12.15 \mathrm{mg} \mathrm{RU} / \mathrm{g}$ de $790 \mathrm{~m}$ ).

Investigation of five different plant extracts from Teucrium chamaedrys (L.) showed high concentration of total phenols, especially flavonoids. Investigation of antioxidant activity of extracts and comparison with the activity of reference substances revealed intense antioxidant activity of plant extracts, 
which was related to high concentration of phenolics in the examined extracts. In addition to its intensive use in the treatment of digestion disorders, gout and various infectious diseases, wall germander (Teucrium chamaedrys (L.) is a potential source of natural antioxidant substances of high value.

\section{REFERENCES}

Blois, M. S. (1958). Antioxidant determinations by the use of a stable free radical. Nature, 18, 1199-1200.

Bozin, B., Mimica-Dukic, N., Samojlik, I., Anackov, G. \& Igic, R. (2008). Phenolic as antioxidants in garlic (Allium sativum L., Alliacea). Food Chem., 111, 925-929.

Faiku, F. \& Haziri, A. (2013). Total lipids, proteins, minerals and essential oils of Taraxacum officinale (L.) growing wild in Kosovo. Int. J. Pharm. Phytopharmacol. Res., 3, 254-257.

Faiku, F. \& Haziri, A. (2015a), Total lipid, proteins, minerals, essential oils and antioxidant activity of organic extracts of Mentha longifolia (L.) growing wild in Kosovo. Eur. Chem. Bull., 4, 432-435.

Faiku, F., Haziri, A., Gashi, F., Troni, N. \& Faiku, F. (2015b). Total lipids, proteins, minerals and essential oils of Pinus nigra Arnold and Pinus sylvestris growing wild in Kosovo. Eur. Chem. Bull., 4, 331-334.

Faiku, F., Haziri, A., Domozeti, B. \& Mehmeti, A. (2012). Total lipids, proteins, minerals and essential oils of Tussilago farfara (L.) from south part of Kosova. Eur., J. Exp. Biol., 2, 1273-1277.

Faiku, F., Haziri, A., Mehmeti, A. \& Reçica, B. (2017a). Antioxidant activity of the organic extracts of Origanum vulgare (L.) growing wild in Kosovo, Fresen. Environ. Bull., 26, 1440- 1446.

Faiku, F., Haziri, A., Mehmeti, I., Muriqi, A. \& Faiku, B. (2017b). Antibacterial Activity of Different Extracts of Daucus Carota (L.) Growing Wild in Kosovo, Res. J. Pharm. Biol. Chem. Sci., 8, 987-991.

Faiku, F., Haziri, A., Mehmeti, I., Bajrami, D. \& Haziri, I. (2016). Evaluation of antibacterial activity of different solvent extracts of Cichorium intybus (L.) grow in wild in east part of Kosovo. J. Anim. Plant Sci., 26, 1486-1491.

Faiku, F., Haziri, A., Mehmeti, I., Mehmeti, A. \& Hoti, Gj. (2018). In vitro antibacterial activity of different solvent extracts of Achillea millefolium (L.) growing wild in Kosovo. Fresen. Environ. Bull., 25, 3878- 3885.

Fukumoto, L. \& Mazza, G. (2000). Assessing antioxidant and prooxidant activities of phenolic compounds. J. Agr. Food Chem., 48, 3597-3604.

Greuter, W., Burdet, H. M. \& Long, G. (1986). Med-checklist: volume 3. Genève, Jardin Botanique, $102 \mathrm{pp}$.

Gursoy, N. \& Tepe, B (2009). Determination of the antimicrobial and antioxidative properties and total phenolics of two "endemic" Lamiaceae species from Turkey: Ballota rotundifolia L. and Teucrium chamaedrys C. Plant Foods Hum. Nutr., 64, 135-140.

Haziri, A., Aliaga, N., Ismaili, M., Govori, S., Leci, O., Faiku, F., Arapi, V. \& Haziri, I. (2010). Secondary metabolites in essential of Achillea millefolium (L.) growing wild in east part of Kosovo, Amer. J. Biochem. Biotechnol., 6, 32-34.

Haziri, A., Faiku, F., Berisha, R., Mehmeti, I., Govori, S. \& Haziri, I. (2017a). Evaluation of Antibacterial Activity of Different Solvent Extracts of Teucrium chamaedys (L.) Growing Wild in Kosovo. Chemistry, 26, 431-441. 
Haziri, A., Faiku, F., Rudhani, I., Mehmeti, I. \& Motori, D. (2017b). Antibacterial Activity of Different Extracts of Centaurea cyanus (L.) Growing Wild in Kosovo, Orient. J. Chem., 33, 1636-1641.

Haziri, A., Faiku, F., Mehmeti, A., Govori, S., Abazi, S., Daci, M., Haziri, I., BytyqiDamoni, A. \& Mele, A. (2013). Antimicrobial properties of the essential oil of Juniperus Communis (L.) growing wild in east part of Kosovo. Amer. J. Pharmacol. Toxicol., 8, 128-133.

Haziri, A., Govori, S., Ismaili, M., Faiku, F. \& Haziri, I. (2009). Essential oil of Tanacetum parthenium (L.) from east part of Kosova. Am. J. Biochem. Biotechnol., 5. 226-228.

Jarić, S., Popović, Z., Mačukanović-Jocić, M., Djurdjević, L., Mijatović, M., Karadžić, B., Mitrović, M. \& Pavlović, P. (2007). An ethnobotanical study on the usage of wild medicinal herbs from Kopaonik Mountain (Central Serbia). $J$. Ethnopharmacol., 111, 160-175.

Kucuk, M., Gulec, C., Yasar, A., Ucuncu, O., Nuran, Y., Coskuncelebi, K., Terzioglu, S. \& Nurettin, Y. (2006). Chemical composition and antimicrobial activities of the essential oils of Teucrium chamaedrys subsp. chamaedrys, T. orientalevar. puberulens, and T. chamaedrys subsp. lydium. Pharm. Biol. 44, 592 - 599.

Kundaković, T., Milenković, M., Topić, A., Stanojković, T., Juranić, Z. \& Lakušić, B. (2011). Cytotoxicity and antimicrobial activity of Teucrium scordium L. (Lamiaceae) extracts. Afr. J. Microbiol. Res., 5, 2692-2696.

Min, G. A. \& Chun-Zhao L., (2005), Comparison of Techniques for the Extraction of Flavonoids from Cultured Cells of Saussurea medusa Maxim. Word J. Microb. Biot., 21,1461-1463.

Nevcihan, G. \& Bektas, T. (2009). Determination of the antimicrobial and antioxidative properties and total phenolics of two "endemic" Lamiaceae species from Turkey: Ballota rotundifolia L. and Teucrium chamaedrys C. Koch. Plant Foods Hum. Nutr., 64, 135-140.

Redžić, S. S. (2007), The ecological aspect of ethno botany and ethno pharmacology of population in Bosnia and Herzegovina. Coll. Antropol., 31, 869-890.

Sanchez-Moreno, C., Larrauri, A. \& Saura-Calixto, F. A. (1998). Procedure to measure their anti-radical efficiency of polyphenols. J. Agr. Food Chem., 76, 270-276.

Sarker, S. D., Nahar, L. \& Kumarasamy, Y. (2007). Microstate plate-based antibacterial assay incorporating reassuring as an indicator of cell growth, and its application in the in vitro antibacterial screening of phytochemicals. Methods, 42, 321-324.

Sharififar, F., Nudeh-Dehghn, G. \& Mirtajaldini, M. (2009). Major flavonoids with antioxidant activity from Teucrium polium L. Food Chem., 112, 885-888.

Stanković, M., Stefanović, O., Čomić, L., Topuzović, M., Radojević, I. \& Solujić, S, (2012). Antimicrobial activity, total phenolic content and flavonoid concentrations of Teucrium species. Rocznik, 7, 664-671.

Stanković, M., Topuzović, M., Marković, A., Pavlović, D., Solujić, S., Nićiforović, N. \& Mihailović, V. (2010). Antioxidant Activity, Phenol and Flavonoid Contents of Different Teucrium Chamaedrys L. Exstracts, Biotechnology \& Biotechnological Equipment, 24, 82- 89.

Tosun, M., Ercisli, S., Sengul, M., Ozer, H. \& Polat, T. (2009). Antioxidant properties and total phenolic content of eight Salvia species from Turkey. Biol. Res., 42, 175181.

Tutin, G. \& Wood, D. (1972). Flora European; volume 3. Cambridge: Cambridge University Press, 57 pp. 
Vlase, L., Benedec, D., Hanganu, D., Damian, G., Csillaq, I., Sevastre, B., Mot, A. C., Silaghi-Dumitrescu, R. \& Tilea, I. (2014). Evaluation of antioxidant and antimicrobial activities and phenolic profile for Hyssopus officinalis, Ocimum basilicum and Teucrium chamaedrys. Molecules, 19, 5490-5507.

Zhishen, J., Mencheng, T. \& Jianming, W. (1999). The determination of flavonoids content in mulberry and their scavenging effects on superoxide radicals. Food Chem., 6, 555- 559.

Zhou, K. \& Yu, L. (2004), Effects of Extraction Solvent on Wheat Bran Antioxidant Activity Estimation. LWT- Food Sci. Technol. Res., 37, 717-721. 